\section{A Revolução na Anestesia Venosa: Sugammadex e Gantracurium}

Prezado Editor,

Nos últimos anos tem-se observado grande avanço em equipamentos e tecnologias aplicadas à anestesia, mas pouco progresso no que diz respeito a novos fármacos em si. A sua introdução na prática médica exige investimentos muito altos e em logo prazo, isto é, implicam pesquisas e experimentações que exigem, na maioria das vezes, grandes estruturas de laboratórios e qualidade de pesquisadores. Recentemente, foram publicados artigos levantando as causas de morbiletalidade em anestesia ${ }^{1,2}$. O mais recente ${ }^{2}$ incluiu 869.483 pacientes e apontou, curiosamente, em uma lista de itens, que o coma ou os óbitos em 24 horas podem ser diminuídos, entre outros motivos, com cuidados com pessoal habilitado e presente ao ato anestésico, bem como com antagonismo de opióides e bloqueadores neuromusculares. Assim, quando nos preocupamos em reverter essas duas classes de fármacos, estamos contribuindo, objetiva e comprovadamente, com a diminuição da morbiletalidade em anestesia. Com relação aos bloqueadores neuromusculares, o que há de mais recente em pesquisas são o Org 25969 (Sugammadex) e AV430A (Gantracurium), que são, respectivamente, um agente reversor e um bloqueador neuromuscular nãodespolarizante, de início e duração mais rápidos do que a succinilcolina.

Há alguns anos pesquisadores vêm se dedicando a estudos de fármacos que possam, não de maneira indireta como a neostigmina, restaurar a transmissão neuromuscular por aumento da concentração de acetilcolina na junção neuromuscular, mas realmente reverter o efeito bloqueador. Esses estudos tiveram como foco a capacidade do agente reversor de diminuir a concentração plasmática do bloqueador neuromuscular, causando um desvio do bloqueador da biofase para o plasma e, em última análise, um deslocamento dele do receptor nicotínico da placa motora para o plasma. As pesquisas então se direcionaram para as ciclodextrinas, moléculas de açúcares, já amplamente empregadas em Medicina como agentes solubilizantes, cujos efeitos são aumentar a solubilidade em água dos compostos-alvo, promover a estabilidade metabólica e a biodisponibilidade de compostos lipossolúveis.

No caso dos bloqueadores, os únicos que são encapsulados por essas ciclodextrinas são os compostos com núcleo esteroidal, em particular, o rocurônio. O complexo dessa gama ciclodextrina, o Org 25969 (Sugammadex) e o rocurônio, agora muito hidrossolúvel, é excretado sem dificuldade pelos rins.

Esse novo agente verdadeiramente reversor vem sendo testado em animais de laboratório e, mais recentemente, no homem, com resultados bastante animadores.
A reversão apresenta algumas características particulares e muito interessantes, como a possibilidade de se obter bons resultados na presença de relaxamento profundo, e a ausência de efeitos cardiovasculares de importância clínica. Os primeiros dois estudos no homem foram apresentados no ASA Meeting $2002^{3}$ e, mais recentemente, em 2005 em Estocolmo, no encontro de cunho acadêmico sobre bloqueadores neuromusculares: Frontiers in Neuromuscular Physiology and Pharmacology" organizado pelo Instituto Karolinska ${ }^{4,5}$. Estes últimos dois estudos, ainda não publicados em revistas especializadas, mostraram em 30 e 87 pacientes respectivamente, que o Org 25969, com doses de 6 a $8 \mathrm{mg} \cdot \mathrm{kg}^{-1}$ injetado em pacientes com graus profundos de bloqueio com rocurônio, promoveu reversão satisfatória em cerca de 2 a 2,5 minutos, sem evidências de recurarização. Também satisfatórios foram os resultados para o aparelho cardiovascular, não havendo alterações na pressão arterial sistólica nem na freqüência cardíaca, visto que não há interação alguma com sistema colinérgico. Em outro trabalho igualmente apresentado no encontro, autores ${ }^{6}$ chamam a atenção que não há necessidade de desvio de todas as moléculas de rocurônio do receptor da placa motora para restauro da transmissão neuromuscular. No entanto, pelo risco de recurarização, a injeção de ciclodextrina deve ser em quantidade suficiente não só para restaurar a função motora, mas para garantir que persistam poucas moléculas de bloqueador no receptor nicotínico muscular.

O outro avanço na anestesia venosa está sendo delineado com o AV430A, denominado Gantracurium. Trata-se de uma nova classe de bloqueadores neuromusculares chamada de clorofumarato, rapidamente inativado por cisteínas plasmáticas, resultando em um fármaco de rápido início de ação e uma ultracurta duração ${ }^{7-9}$.

A DE95 é de $0,19 \mathrm{mg} \cdot \mathrm{kg}^{-1}$ e o tempo para atingir $90 \%$ do bloqueio é de 122 a 54 segundos, na dependência da dose administrada. A duração clínica (T25\%) é igualmente muito curta, em torno de 3,5 a 10 minutos $^{7,8,10}$. Em animais de laboratório, a reversão é obtida com facilidade com a injeção de cisteína ${ }^{11}$ e em seres humanos foi acelerada com o uso de edrofônio ${ }^{12}$.

Em experimentação animal e no homem, a injeção da droga mostrou insignificantes efeitos colaterais em doses até três vezes a DE95 ${ }^{13,14}$. A presença de discreto aumento da freqüência cardíaca e diminuição da pressão arterial média foi observada somente com doses superiores a cinco vezes a DE957,14.

Estudos multicêntricos com Sugammadex em seres humanos estão sendo desenvolvidos, e a perspectiva de sucesso desse novo agente reversor é bastante positiva. A expectativa da disponibilidade comercial do AV430A, um bloqueador que possa substituir a succinilcolina, também é bastante aguardada.

Se esses dois fármacos forem liberados para uso clínico, pode-se dizer que um novo marco na anestesia foi alcançado: um bloqueador com rápido início de ação para adminis- 
tração nas situações de emergência e uma reversão segura sem o perigo da curarização residual e nem de efeitos colinérgicos indesejáveis.

Maria Cristina Simões de Almeida, TSA

Doutora pela Universidade Johannes

Gutenberg/Alemanha; Professora Adjunta da UFSC.

\section{A Revolution in Intravenous Anesthesia: Sugammadex and Gantracurium}

\section{Dear Editor,}

The last several years have seen significant developments in the equipment and technologies applied to anesthesia but little progress regarding new medications. Introducing new drugs in the medical practice demands a great amount of investment over a long period of time, i. e., research and experiments that demand, in most cases, large laboratories and experienced researchers.

Several articles have been published recently reporting the morbidity and the mortality in anesthesia ${ }^{1,2}$. The most recent ${ }^{2}$ included 869,483 patients showing, amazingly, in a list of items, that coma or death within 24 hours can be reduced by, among other measures, carefully selecting experienced personnel to perform the anesthesia, as well as with the use of opioid and neuromuscular blockers antagonists. Therefore, when we worry about reverting the effects of these two classes of medications, we are contributing, objectively and corroboratively, to reduce the morbidity and mortality of anesthesia. Regarding neuromuscular blockers, the most recent studies focused on Org 25969 (Sugammadex) and AV430A (Gantracurium), which are, respectively, a neuromuscular reverser and a non-depolarizing blocker, whose beginning and duration of action are faster than that of succinylcholine.

For some years now researchers have been studying drugs that can restore neuromuscular transmission, not indirectly like neostigmine, which increases the concentration of acetylcholine in the neuromuscular junction, but actually reversing the blocking effect. The focus of these studies was the ability of the reverting agent to decrease the plasma concentration of the neuromuscular blocker, causing a deviation of the blocker from the biophasis to the plasma and, in last instance, displacing it from the nicotinic receptor in the motor plate to the plasma. The studies are directed to the cyclodextrins, sugar molecules widely used in Medicine to increase the solubility of the target compounds in water, promote the metabolic stability, and the bioavailability of liposoluble compounds.

In the case of blockers, the only compounds encapsulated by these cyclodextrins are those with a steroidal nucleus, especially rocuronium bromide. The complex of this gamma cyclodextrin, Org 25969 (Sugammadex) and rocuronium bromide, now extremely hydrosoluble, is easily excreted by the kidneys.

This new agent, a true reverser, has been tested in laboratory animals, and more recently in man, and has presented encouraging results.

The reversal presents especial and interesting characteristics, such as the possibility of obtaining good results in the presence of a deep relaxation, and the absence of clinically important cardiovascular effects. The first two results in man were presented in the ASA 2002 Metting $^{3}$ and, more recently, in 2005 in Stockholm in the academic meeting about Neuromuscular Blockers: Frontiers in Neuromuscular Physiology and Pharmacology organized by the Karolinska Institute ${ }^{4,5}$. Those last two studies, yet to be published in specialized journals, showed that in 30 and 87 patients, respectively, Org 25969 administered in doses ranging from 6 to $8 \mathrm{mg} \cdot \mathrm{kg}^{-1}$ to patients with deep blockade by rocuronium bromide promoted satisfactory reversal of the blockade in 2 to 2.5 minutes without any evidence of recurrence of curarization. The results in the cardiovascular system were equally satisfactory because there were no changes in systolic blood pressure or in cardiac frequency, since there are no interactions with the cholinergic system. In another study presented in this meeting, the authors ${ }^{6}$ showed that it is not necessary to remove every molecule of rocuronium bromide from the motor plate receptor to restore the neuromuscular transmission. However, due to the risk of recurrence of curarization, cyclodextrin should be injected in an amount capable of not only restoring motor function, but also guaranteeing that few molecules of the blocker remain in the muscular nicotinic receptor. The other development in intravenous anesthesia is being delineated by the AV430A, called "Gantracurium". It belongs to a new class of neuromuscular blockers called chlorofumarate, which is rapidly deactivated by plasma cysteines resulting in a pharmacologic compound with a rapid onset of action and very short duration ${ }^{7-9}$.

The DE95 is $0.19 \mathrm{mg} \cdot \mathrm{kg}^{-1}$ and the time to achieve $90 \%$ of the blockade ranges from 122 to 54 seconds, depending on the dose administered. The clinical duration (T25\%) is equally short, around 3.5 to 10 minutes $^{7,8,10}$. In laboratory animals the reversal is easily obtained with the injection of cysteine ${ }^{11}$, and in human beings it has been accelerated by the use of edrophonium $^{12}$.

In experiments in animals and in men the injection of the drug showed little side effects in doses up to 3 times the DE95 $5^{13,14}$. The presence of a discrete increase in cardiac frequency and reduction of the mean arterial blood pressure was only observed with doses higher than 5 times the DE95,14.

Multicenter studies with "Sugammadex" in human beings are developed and the perspective of success of this new reverser agent is very positive. The commercial availability of the AV430A, a blocker that can substitute succinylcholine, is equally awaited. 


\section{CARTAS AO EDITOR / LETTERS TO THE EDITOR}

If these two drugs are approved for clinical use, one can say that a new landmark in anesthesia has been achieved: a blocker with a fast onset of action to be administered in emergency situations and a safe reversal without the danger of residual curarization or the undesirable cholinergic effects.

\author{
Maria Cristina Simões de Almeida, TSA, M.D. \\ Doutora pela Universidade Johannes \\ Gutenberg/Alemanha; Professora Adjunta da \\ UFSC.
}

\section{REFERÊNCIAS - REFERENCES}

1. Olsson GL, Hallen $B-$ Cardiac arrest during anaesthesia. $A$ computer-aided study in 250,543 anaesthetics. Acta Anaesthesiol Scand, 1988;32:653-664.

2. Arbous MS, Meursing AE, van Kleef JW et al - Impact of anesthesia management characteristics on severe morbidity and mortality. Anesthesiology, 2005;102:257-268.

3. Gijsenbergh F, Ramael S, Houwing $\mathrm{N}$ et al - First human exposure of Org 25969, a novel agent to reverse the action of rocuronium bromide. Anesthesiology, 200. Anesthesiology, 2005;103:695-703.

4. Khuenl-Brady K, Rex C, Sielenkamper A et al - Reversal of highdose rocuronium with Org 25,969, Frontiers in Neuromuscular Physiology and Pharmacology. Estocolmo, 2005.
5. Shields M, Giovannetti M, Moppett I et al - Deep neuromuscular block reversal with ORG 25,969, Frontiers in Neuromuscular Physiology and Pharmacology. Estocolmo, 2005.

6. Skinner C, Bon A - Effect of magnesium on neuromuscular function after reversal of rocuronium-induced neuromuscular block of mouse isolated hemi-diaphragm contractions by different concentrations of Org 25 969. Frontiers in Neuromuscular Physiology and Pharmacology. Estocolmo, 2005.

7. Belmont MR, Lien CA, Tjan $\mathrm{J}$ et al - Dose-response relations of 430A under propofol, nitrous oxide, opioid anesthesia, ASA Meeting, 2003;A1153.

8. Belmont MR, Lien CA, Tjan $\mathrm{J}$ et al - Clinical pharmacology of GW280430A in humans. Anesthesiology, 2004;100:768-773.

9. Lien CA - The Pharmacology of GW280430A: A New Nondepolarizing Neuromuscular Blocking Agent. Seminars in Anesthesia, Perioperative Medicine and Pain, 2002;21:86-91.

10. Lien CA, Belmont MR, Heerdt PM - GW280430A: pharmacodynamics and potential adverse effects. Anesthesiology, 2005; 102:861-862; author reply 862-3.

11. Belmont MR, Horochiwsky Z, Eliazo RF et al - Reversal of AV430A with cysteine in rhesus monkeys, ASA Meeting, 2004;A1180.

12. Lien CA, Belmont MR, Tjan J et al - Pharmacodynamics of spontaneous and edrophonium-facilitated recovery following administration of 430A, ASA Meeting, 2003;A1154.

13. Savarese JJ, Belmont MR, Hashim MA et al - Preclinical pharmacology of GW280430A (AV430A) in the rhesus monkey and in the cat: a comparison with mivacurium. Anesthesiology, 2004; 100:835-845.

14. Belmont MR, Tjan J, Lien CA et al - The preliminary cardiovascular profile of AV430A in humans, ASA Meeting, 2004;A1145. 